\title{
Personal Names in the Families of Russian Germans: Challenges of Self- Identification of the Ethnic Group
}

Daniya Abuzarovna Salimova ${ }^{\dagger}$ and Larisa Borisovna Bubekova ${ }^{*}$

\section{Abstract}

The research deals with the topical issue of changing the 'ethnolinguistic and cultural area', a shift in the system of ethnolinguistic and cultural orientations and values of the people. The problem is discussed from the perspective of anthroponymic material in the families of ethnic Germans born in Russia, whose ancestors settled on Russian lands since the reign of Catherine II. The primary purpose of the study is to carry out a comprehensive analysis of some (often controversial) aspects of (self)identification of the linguistic personality of Russian Germans from the perspective of the corpus of personal names. Using the methods of functional historical analysis, continuous sampling, interview, systemisation, and interpretation, the authors of this study, based on the analysis of a relatively large corpus of collected personal names, as well as based on answers of 200 respondents, who are descendants of Russian Germans, attempted to determine which names are chosen for children and what language Russian Germans speak today. The problem is considered from a synergistic perspective: sociolinguistics, linguoculturology and ethnolinguistics, as well as anthroponymics. The authors conclude that the choice of names in the families of Russian Germans of German/non-German origin depends on several factors - traditions of the family; place of residence; the level of education; profession/specialisation. In the anthroponymicon of Russian Germans, under the influence of personal names of the surrounding ethnic groups, socio-cultural and historical changes result in internal changes in language units.

Keywords: Russian Germans; Culture; Family; Anthroponym; Language as Native; Language as Non-native; Bilingual, Linguistic Consciousness, Interlingual Personality; Ethnic Codes

\footnotetext{
${ }^{+}$Doctor of Philological Science, Professor of Russian Language and Literature Department of Yela-buga Institute of Kazan Federal University, the Republic of Tatarstan, Russia, Email: daniya.salimova@mail.ru ${ }^{*}$ Corresponding Author, Email: bular@yandex.ru

* Candidate of Philological Science, Associate Professor of Russian Lan-guage and Literature Department of Yelabuga Institute of Kazan Federal University, the Republic of Tatarstan, Russia

(C) 2020 Salimova \& Bubekova. This is an Open Access article distributed under the terms of the Creative Commons Attribution License (http://creativecommons.org/licenses/by/2.0), which permits unrestricted use, distribution, and reproduction in any medium, provided the original work is properly cited.
} 


\section{Introduction}

One of the most rapidly developing areas in modern domestic and Western humanities is the study of a wide range of issues related to the formation and development of nations and national identity. The authors managed to work on a topic related to Russian Germans as part of a grant from the Russian Humanitarian Science Foundation in the period of 2015-2017, which made it possible to accumulate the material in various fields reflecting the life and language of the Germans in Russia. The interest in continuing the research remained after the completion of the grant project: there are still personal contacts, unpublished materials.

This research aims to investigate the personal names in the families of Russian Germans. In doing so, the study examines the problem of self-identification of the ethnic group. According to the 1989 Census, 2 million 38 thousand Germans lived in the USSR (Union of Soviet Socialist Republics), of which 842 thousand people lived in the RSFSR (Russian Soviet Federative Socialist Republic) (spell out full form please). After 13 years, according to the 2002 Census, about 600 thousand Germans remained in Russia. The 2010 Census registered 394,138 Germans in Russia, that is, just within eight years, the number of Germans decreased by one third - 203,074 people (34\%) less than in 2002. Such significant discrepancies in the number and composition of representatives of the ethnic group in the near decades are not observed anymore in relation to any other nation. Indeed, the point is primarily in political and economic conditions (after the 1990s, as many Russian Germans left for Germany for permanent residency), but the spiritual-moral, historicalsocial background in the country also plays an important role (Magsumov, 2019). Unfortunately, it has kept a certain negative attitude towards both Germans and everything German. In the next section, we discuss the methods and methodological issues linked to our research.

\section{Materials and Methods}

The source-study base of the study included as follows: face-to-face interviews (trips to Kazan, Izhevsk, Mozhga, Moscow, Bishkek, meetings in Yelabuga), as well as correspondence with descendants of Russian Germans. For this, over 200 representatives of Russian Germans aged from 18 to 80 years old took part in the survey; in most cases, though correspondence and exchange of voice messages were implemented using social networks - VKontakte.ru). Besides, the research deployed chrestomathies and encyclopaedias, and other archival materials, in particular: History of Germans in Russia: Chrestomathy (German et al., 2005); Russian Germans of the 21st Century: Materials of the International Scientific-Practical Conference and Sociological Survey, Moscow, 2008 (Russian Germans. 21st Century, 2008); Aumann and Chebotarev (2008).

Archival materials testify to the roles of Russian Germans in the development of higher education of Yelabuga Pedagogical Institute and other linked activities. In a time period of two year, this research has analysed more than 500 names and surnames belonging to the families of Russian Germans.

It should be noted that the ethical aspect of the interviews did not cause any particular problems, however, few respondents refused to give any information of their families, making no secret of the fact that they still experienced the "fear of 1941" (The German population of Russia was in fear of reprisals, because in the eyes of the local population with the outbreak of war, the Germans began to be associated with the Nazis. So, from June 22 to August 10, 1941, 145 Volga Germans were arrested in the Republic, including 2 for espionage, 3 for "terrorist intentions," 4, and 4. The rest were arrested. mainly for "defeatist and rebel statements." Information portal of Russian Germans https://geschichte.rusdeutsch.ru/21/34).

One can recall that in August of 1941, Russian Germans and their Volga autonomy were expelled from their native lands. 
The findings of this research carry values and practical novelty. The findings can not only be used in the direct practice of school counsellors but also research activities, in the training of teachers of the Russian and German languages. It is essential from a both scientific and educational perspective to study the vector of the formation and development of RussianGerman bilingualism and to measure the competencies in each of the ethnolinguistic cultures through the anthroponymic corpus both in connection with the levels of direct language training and taking into account the features of its ethnolinguistic and sociocultural environment.

The novelty and relevance of the topic lie in the fact that studies of the linguo-culturological component of the groups of Russian Germans in the language perspective are not conducted enough, especially in the context of today's changes.

Different sciences have been studying the phenomenon of "Russian Germans" for many years. Well-known scholars in various fields covered the topic in great detail; the authors have also tried to make a modest contribution by spelling out a brief overview of the degree of knowledge of the topic in earlier publications (Aumann and Chebotarev, 2008; Bogoslovskaya and Shchegolikhina, 2015; Bozhkova et al., 2019; Chebotaryova, 1997; Danilova et al., 2016; Dinges, 2006; Dolgih and Asatiani, 2015; Hedderich, 2010; Frolova et al., 2019; Salimova and Danilova, 2016).

The main objective of this research is to analyse the relationship between the self-identification of the ethnos/personality of the Russian Germans and a corpus of personal names in their families. In this context, the problem of preserving ethnocultural codes among Russian Germans also comes to the fore. It is associated primarily with the motivation of those who, being German, voluntarily and deliberately did not indicate their affiliation to the RussianGerman people. What is it connected with? They not indicate their affiliation to the RussianGerman people either caused of the lack of desire to preserve their ethnocultural codes or "muted" genetic codes played a decisive role in this decision.

\section{Discussion}

In social and humanitarian knowledge, the term "identity", introduced for the first time by Erich Erikson (Erikson, 1968), is understood as a person's self-image, his/her "I", who he/she is in this world, the way he/she sees and perceives his/her status in relation to the language and national identity. National identity includes many components: worldview, national identity, mentality, historical memory, ethnonational images and symbols, traditions, etc. Language, within the ethnic boundaries of its speakers, is not only a means of communication but also the memory and history of its people, its culture and experience of cognitive activity; it is the knowledge of the surrounding reality that has been fixed from generation to generation; in other words, language is a cognitive base of an ethnic group.

It is known that there are several concepts of defining Russian Germans as an ethnic group. The authors are more interested in the concept of Russian-German identity, which is substantiated by Baumgertner and Wormsbecher: they recognise the Russian Germans as a separate young ethnic group that is different from the closely related old German nation and has specific features compared to the Russian nation. In the authors' opinion, a slogan "We are [the] Germans, we are citizens of Russia" confirms the particular ethnic history of Russian Germans. Thus, one can conclude that this point of view is inherent in the "avantgarde" part of the Russian Germans, which constitutes the population of the high-density areas. Here is what the Soviet and Russian writer, Russian German Vormsbecher writes about it: "In Russia, for two and a half centuries from the diaspora, from a fragment of the people of another country, its Germans became independent, new people on the planet, much more meaningful, internally richer than they had been before. In Russia, they became part of the great mixed people of the great country. Here, in the process of their difficult history, those 
national traits crystallised, which helped them to stand and survive" (Vormsbekher, 2009, p. 199).

Not only the data of face-to-face meetings but also the messages on the Internet of the studied groups of people were of interest. Observations and the analysis of many groups created by Russian Germans and for Russian Germans over the past three years have allowed discovering an expected and explicable idea: to unite all citizens related to the history of Russian Germans. In groups of the social network VKontakte there is a massive number of groups of Russian Germans (Saenko et al., 2019). It is important to note that the authors, at the same time, deliberately did not touch the topic of special sites and portals for Russian Germans. In recent years, the authors have not only studied text messages but also held consistent correspondence with the active members of these groups, analysed questionnaires that were kindly distributed by active and open-minded representatives of the Russian Germans. Like any groups, the "Russian Germans" groups consist of: a) participants (people who know the history of Russian Germans, who are directly relatives of Germans in Russia, participating in the life of Russian Germans); b) discussions (a creator of a group or its members suggests a topic for discussion). All group members are involved in the discussion; however, they may not express their opinion on this issue); c) posts on the wall (if a group is not closed, any person can visit the group and see which events will take place in the near future, in which competitions one can participate); d) video and audio recordings (songs in the Russian and German languages, videos about myths about Russians and Germans ); e) additional sources (references) by means of which one can learn more information and dive deeper into the topic.

Each group has an individual name reflecting the idea of a group. The double name of these groups speaks of the acceptance by members of both German and Russian languages. It should be noted that many participants in the groups divide Russian Germans into two categories: Russian and Russia Germans: by the way, not all Russia Germans in the groups consider themselves to be Russian Germans since they do not live in Russia. The selection method was used to study objects, the elements of which do not have the qualitative uniformity of features that are significant from the point of view of research objectives.

Although a large number of groups of Russian Germans were discovered, only nine of the most interesting and informative groups, in the authors' opinion, were selected:

- Russian Germans in Balakovo City (Российские Немцы в г. Балаково)

- Germans in VKontakte (НЕМЦЫ В KOHTAKTE)

- Wiedergeburt (Russian Germans in Perm) (Wiedergeburt (Российские немцы Перми))

- Young Russian Germans in Kazan City (МОЛОДЫЕ РОССИЙСКИЕ (РУССКИЕ) НЕМЦЫ Г. КАЗАНИ)

- I want to go home - to Germany! Or German people in Russia (Хочу домой В Германию! Или Немцы и Немки в России)

- Russian Germans! Our music in Germany (Русские НЕМЦЫ! Музыка Наших в Германии)

- Russian Germans (Российские немцы)

- Russian Germans (РОССИЙСКИЕ НЕМЦЫ)

- Russian Germans (Российские Немцы)

As you can see, the names of the groups are very similar in content. They differ only in their graphic design, which is reflected in Figures 1, 2, 3. 


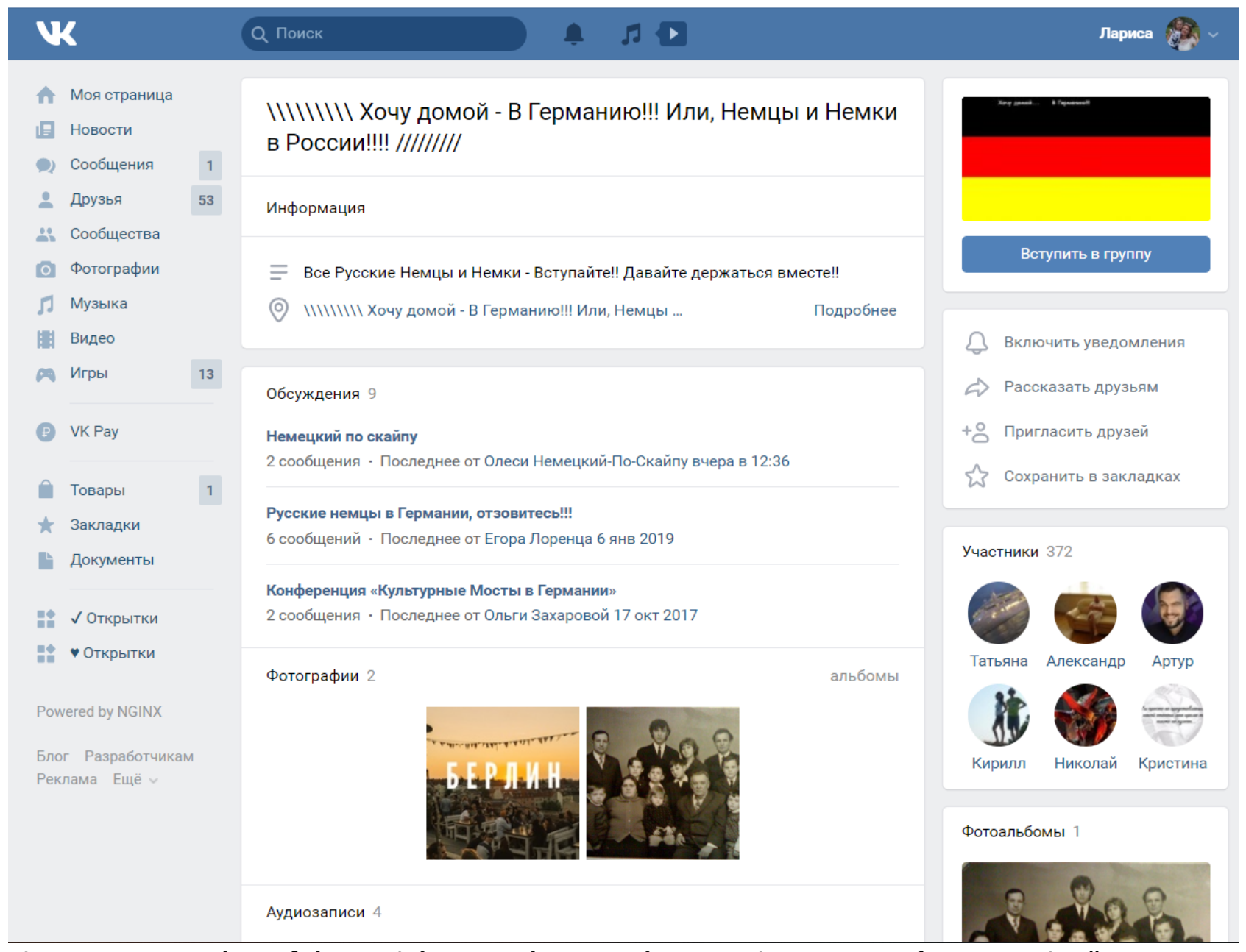

Figure 1: Screenshot of the Social Network VKontakte. Russian Germans' Community "I want to go home - to Germany! Or German people in Russia".

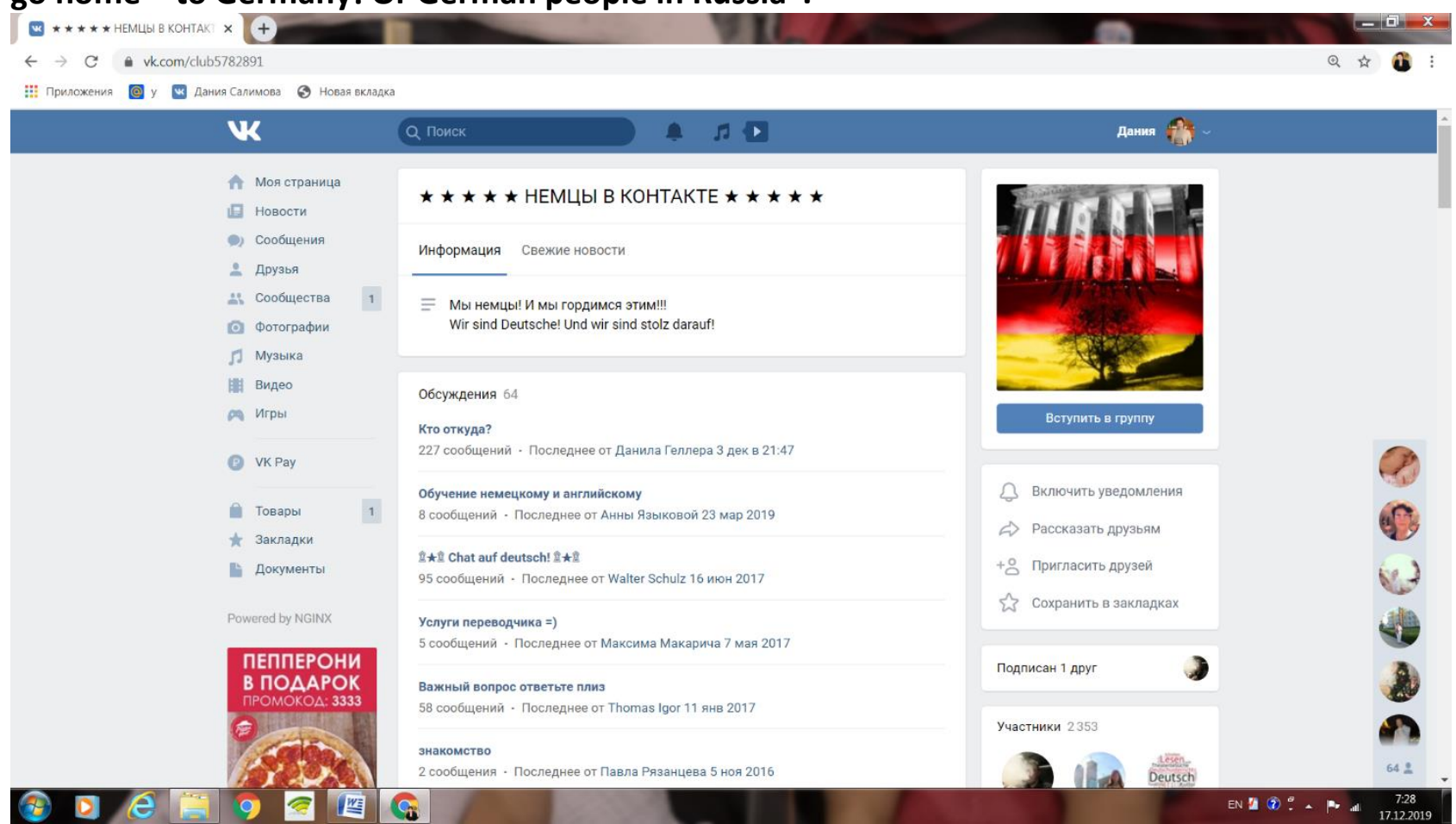

Figure 2: Screenshot of the Social Network VKontakte. Russian Germans' Community “Germans in VKontakte". 


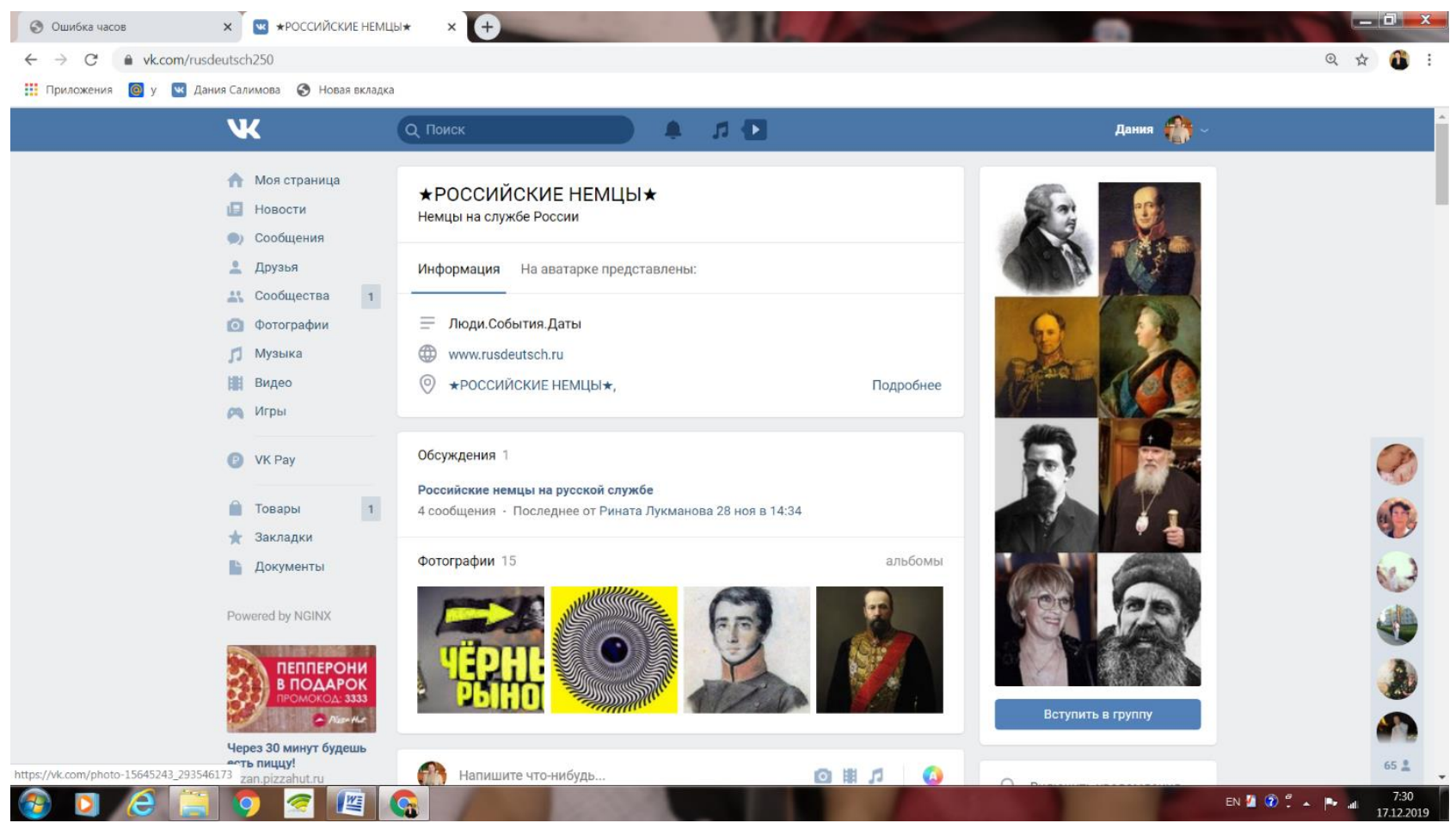

Figure 3: Screenshot of the Social Network VKontakte. Russian Germans' Community “Russian Germans".

The parameters by which the authors identified conditions are created, would you learn (or the most significant groups in the social network improve) German? 9. How do you see your are as follows: 1. Informational value. 2. "Germanness"? Do you like German meals, songs, Communicability. 3. Publicity. 4. Good holidays? 10. Will you teach your children the organisation. These groups in social networks German language?

allow Russian Germans to discuss not only the The research established direct contacts with 50 attitude of other nationalities towards Russian representatives of Russian Germans. The Germans but also the place of the next gathering stratification of the studied society was carried out of Russian Germans in Russia and Germany, according to the following criteria: gender, age, premieres, national cultural events, and others. level of education, place of residence.

These sites helped us find participants, and upon Let us cite selective fragments from messages agreement, suggested them to fill out a where the basic information concerns names. questionnaire.

Ksenia Nikolaevna Rohrmoser, born in 1972 (ancestors: Elfrida Albertovna, Emma The questionnaire (short version) contained the Ludvigovna; Albert Frantsevich, Franz following questions: 1. Your full name. 2. Age, Rohrmoser). Vladimir Aleksandrovich Shengals, education, do you know the history of Russian born in 1955 (Katerina Friedrichovna, Nellya Germans? 3. Full name of your grandparents Ivanovna Gross); Yuri Vladimirovich Nachtigal, (where they come from). 4. What is your born in 1964 (Vladimir Avgustovich Nachtigal, nationality? 5. What language do you recognise as progenitors - August Ottovich, Yossifina native and first, what language is foreign? 6. In Gustavovna Klein); Alexander Sergeevich Faller, your opinion, who are the "Russian Germans": 1981 (parents - Sergei Jansen and Natalya Faller, representatives of the German nation, grandfather-Faller Blasius). representatives of the Russian nation or an Here is what Svetlana W. writes (she gave her independent ethnic group? 7. Are you going to consent to the publication of her letter), she is a move to Germany? If yes/no, say why? 8. How do former German teacher of the Yelabuga State you assess the level of proficiency in German? If Pedagogical Institute, the authors' active 
respondent. At present, despite her age, she is actively involved in the events of the House of German-Russian Friendship in Kazan city. "My father's name is Konrad Konradovich, my grandmother's name from the father's side was Markatrina - an abbreviated name, the full name sounds like Maria-Katerina. The Germans still have a tradition to give to a child two names, my grandfather's name was Konrad, and my father's brothers' names were Adam and Christian. My mother's parents' names were Amalia, Karl, her sisters' names were Maria, Elsa, her brother's name was Waldemar, but they called him Volodya, she got the name Lydia - this is also a name with European roots, although it is often found in the Russian language. My mother's friends' names were Emma and Frida. Her sister Maria's husband's name was Daniel, their sons were Arvid, Walter, Friedrich. All these names are of German origin. My father's brother Christian called his son by a German name Johannes, but everybody calls him Vanya. My parents chose names for their daughters with Russian roots (although I don't know their exact origin): Nina, Tamara, Svetlana, Lyudmila. My grandchildren are Vadim, Masha - Maria; there is a connection with an international name. My sister Lyuda (her husband is Russian German) has sons - Sasha, Kostya; grandsons - Roman (this name is in German too), Angelina (in German it sounds like Angelika), Georgiy (in German it sounds like Georg) and Victoria (with European roots)".

The preliminary conclusions are as follows. German roots are most vividly reflected, which is quite expected, in the following names: Battenberg, Welsh, Heinrichs, Gertner, Danker, Diel, Seyfert, Kuxhausen, Leinweber, Meisner, Nain, Plater, Craytor, Ratner, Saibel, Frese, Friedmann, Stukkert, Erich and other names.

In the memoirs of grandchildren, their grandparents mainly had the following German names: Angelika, Waldemar, Georg, Johannes, Matilda, Conrad, Frida, Erich, Merkera, Edmund, Elsa, Christian.

A name, surname and middle name with German roots are less common among the respondents:
Anna Frantsevna Weimer (1945), Konrad Genrikhovich Hoffman (1945), Amariya Karlovna Stukkert (1937). As can be seen from the list, these are mostly elderly people. Such a "complete set" occurs among young descendants much less common: Elvira Genrikhovna Keyler (1973).

Today, more often the children of Russian Germans have the following names: Alexandra, Anna, Boris, Victor, Evgeniy, Ekaterina, Elena, Regina, Christina, Ksenia, Victoria, Julia.

\section{Results}

The results of the work are as follows: 1 . The systematised database according to the data of the respondents of different generations with the analysis of their names/surnames, as well as linguistic and cultural preferences (200 respondents who were directly involved in the survey). 2. Proposals on the methods of language and cultural stimulation and maintenance of bilingual and bicultural RussianGerman children and adolescents in public and private educational institutions in order to preserve identity and prevent mental disorders (often based on insufficient ethnic self-identity).

The authors' conclusion is as follows: bimentality, bilingualism and biculturalism of ethnic Germans are provoked by extralinguistic factors. As one respondent said: "I am German, of course, and always say that I am German, but I am very ashamed that I do not know German. And I can only blame myself. Now I attend courses, learn the language, but it is hard, I had to do it earlier". Thus, there is a significant gap between national identity and national language, which adversely affects the nature of identity and radically transforms the qualitative characteristics of the ethnic community of Russian Germans.

Almost one hundred per cent of the families of the Volga Germans had German-originated names. Let us recall that even a birth certificate and a work record were issued to them in German (Figure 4). 

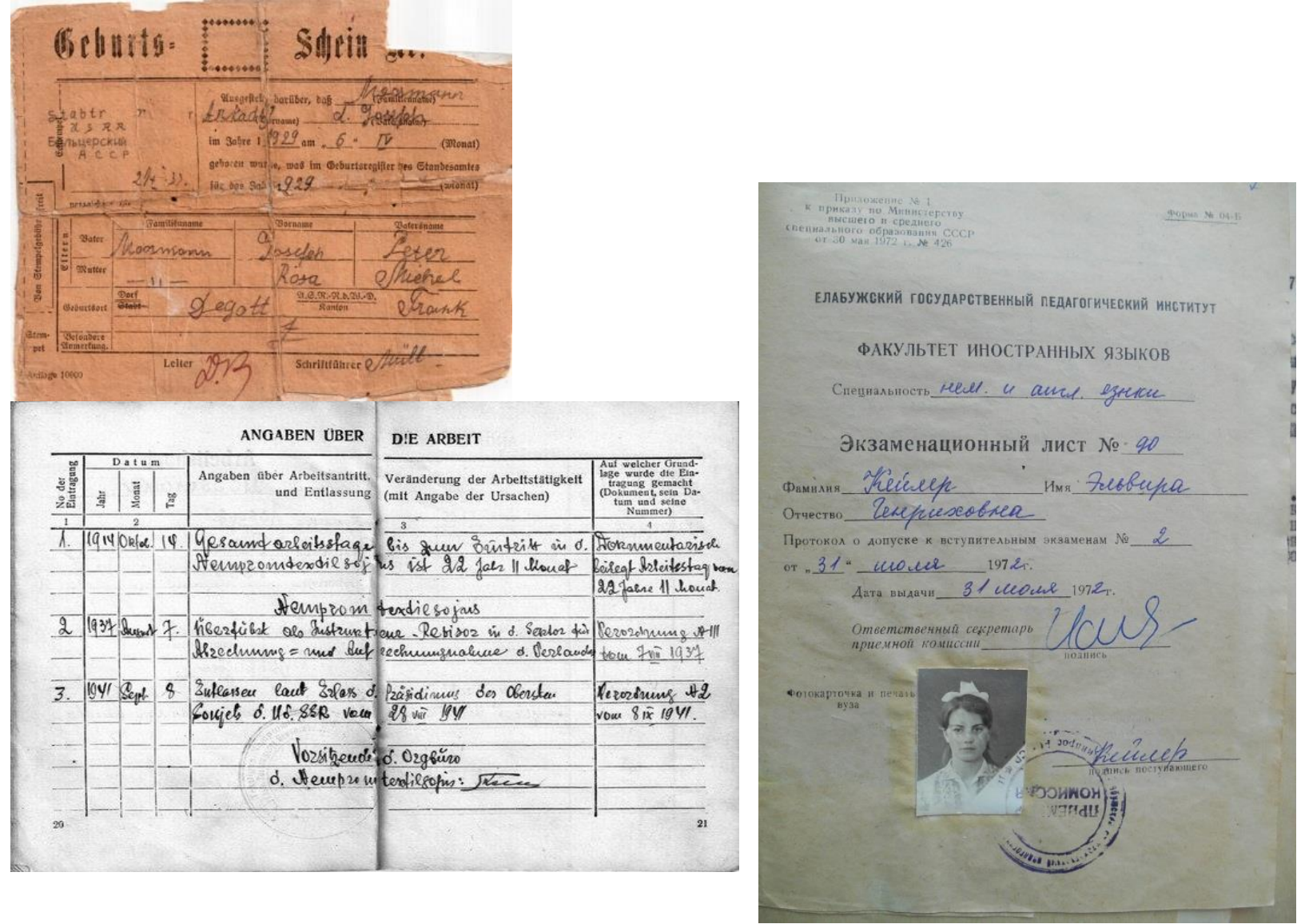

Figure 4: Documents from the Collections of the History Museum of Yelabuga Institute of Kazan Federal University

In the analysed families of Russian Germans, German roots in the names are clearly visible among grandparents by 92 per cent (they are about 70-80 years old), 30 per cent of their children (40-60 years old) and only 20 per cent of grandchildren reflect Germanness. Surnames in 98/70/40 per cent, respectively.

At the same time, among the respondents, there are names and surnames that are not recorded in German personal name dictionaries, which are commonly available in Russia, such as Aumann, Burbach, Haller, Girnstein, Moos, Pundani, Wittneben, Dell, Kiser, Kuksgauzen, Netsel, Landays, Leinweber, Stadler, Shtertser, Dirlam, Buterus, Gallinger, Hughe, Groo, Meisner, Rayfegerst, Raymer, etc.

Thus, it can be concluded that the descendants of Russian Germans who now live in Krasnoyarsk, St. Petersburg, Mozhga and other cities, having found themselves in a kind of conservation, preserved their ancient names. It is quite possible that in the conditions of dispersed residence, also surrounded by speakers of other languages (Tatar, Kazakh, Udmurt, etc.), certain phonetic transformations occurred in names and surnames of Russian Germans; for example, the researchers encountered names such as Andre and Anre, Frize and Freze, Elizaveta and Elizabeth, Moosman and Mosman, Groo and Gro, Grek and Greg, Welk and Wolk. For example, one of the most common female names - Ekaterina, is found in the variants: Katerina, Katy, Kate. These options are common in social networks and groups, which is a kind of projection of different name recoding in registry offices and Lutheran churches.

Conversely, the researchers have not come across the names and surnames recorded in the list of the most frequent German names, such as Agna, Atala, Annelis, Barbel, Brunhildt, Gertrude, Dagmar, Karl, Kurt, Köhler, Koenig, 
Kirsa, Lange, Werner, Wolf, Sommer, Herman, Hofmann, Schultz, Erna, and others . In particular, the first ten of frequently indicated surnames with clear semantics ("speaking surnames"): Müller, miller; Schmidt, blacksmith; Schneider, tailor; Fisher, fisherman; Meier, property manager; Brown, brown, Weber, weaver; Wagner, carriage master, cartwright; Becker, baker; Klein, small; Schulz, headman; Hoffmann, courtier are absent among the respondents. Apparently, there are severe differences in the occurrence of names/surnames in Russia and Germany.

Indeed, the researchers recognise a particular limitation of the sample that one should not draw premature substantive conclusions based on only 500 names and surnames; however, specific changes, tendencies in the naming of Russian Germans are evident. It can be argued that a name is actually a sign of individuality; it is also a social phenomenon, as it introduces its carrier into the social continuum, inscribing him/her into the historical and cultural space (Pavlyshyn et al., 2019).
Undoubtedly, it is also crucial that approximately 40 per cent of young respondents in social networks indicate their name and surname in the Latin script: Andreas Dell, Boris Waldemar von Leinweber, and others. Approximately 10 per cent of young respondents are actively involved in the national movement of Russian Germans: these are societies of Russian-German friendship, Sunday schools, language internships, and others.

The researchers also admit that among the names/surnames there can be pseudonyms that serve the purposes of anthroponymic nomination, that is, there could be fictitious names in the "German guise". For example, these can include a surname Dech, which is consonant with the Russian pronunciation of Deutsch.

Below are two summarising Tables (Table 1 and Table 2), in which a correlation between the age of the participants and their proficiency in German is clearly seen:

\begin{tabular}{|c|c|c|c|c|}
\hline \multicolumn{3}{|l|}{ Table 1: Correlation Between the Age of the Participants and their Proficiency in German } \\
\hline $\begin{array}{l}\text { Age of } \\
\text { Respondents }\end{array}$ & $\begin{array}{l}\text { Name/Surname of } \\
\text { German Origin }\end{array}$ & $\begin{array}{l}\text { Level of Proficiency } \\
\text { in Russian } \\
\text { (high, average, low) }\end{array}$ & $\begin{array}{l}\text { Level of } \\
\text { Proficiency in } \\
\text { German } \\
\text { (high, average, } \\
\text { low) }\end{array}$ & $\begin{array}{l}\text { Proficiency in } \\
\text { another foreign } \\
\text { language } \\
\text { (yes/no) }\end{array}$ \\
\hline $18-40$ & $41 \%$ & high & average & Yes (40\%) \\
\hline $40-60$ & $72 \%$ & high & low & No (91\%) \\
\hline $60-80$ & $98 \%$ & average & high & No (92\%) \\
\hline Source: Own Research & & & \\
\hline
\end{tabular}

\begin{tabular}{|l|l|l|l|l|}
\hline \multicolumn{3}{|l|}{ Table 2: Correlation Between the Age of the Participants and their Proficiency in German } \\
\hline $\begin{array}{l}\text { Gender of } \\
\text { Respondents }\end{array}$ & $\begin{array}{l}\text { Number of } \\
\text { People }\end{array}$ & With Higher Education & $\begin{array}{l}\text { Proficient in } \\
\text { German }\end{array}$ & $\begin{array}{l}\text { Proficient in Another } \\
\text { Foreign language }\end{array}$ \\
\hline Men & 80 & $90 \%$ & $70 \%$ & $52 \%$ \\
\hline Women & 120 & $94 \%$ & $80 \%$ & $76 \%$ \\
\hline Source: Own Research & & &
\end{tabular}

These data are virtually independent of gender; the only thing that catches one's eye is that there are much more women among the young respondents who speak English in addition to Russian and German.
Undoubtedly, the following factor played its role - the parents, who gave their children names with German etymology, are from a group that is not indifferent to their ethnic roots and who strives to preserve the memory of their 
ancestors at least in an anthroponymic design. Thus, the personal name of the Russian Germans can be assessed as a very bright ethnocultural code.

At the same time, it is noteworthy that amongst the participants, who are the descendants of the Russian Germans, in the names and surnames of which Germanic etymology can be traced, hardly speak German, but they do not deny their "Germanness". Not by accident, when answering "Can you call yourself a Russian German if you do not know German?" - 80 per cent of respondents answered in the affirmative.

\section{Conclusion}

Methods of functional historical analysis, continuous sampling, considered from a synergistic perspective; the systematisation of answers and interviews of 200 respondents, who are descendants of Russian Germans allowed us to come to the conclusion that the choice of names in Russian Germans' families of German / non-German origin depends on a number of factors: these are traditions of the family; place of residence (in the families who left for permanent residence in Germany, naturally, the percentage of people with names with German origin is much higher); the level of education; profession / specialisation (almost 80 per cent of the descendants of Russian Germans, who now live in different regions of Russia and are engaged in the national-cultural movement, have names with the German etymology: Martha, Christina, Franz, Henri).

There are exceptions to this rule, when the cultural traditions of the ancestors were preserved at the level of "genetic memory" and were not supported from the outside. As a perfect example can be considered a girl with a name Guzel L. Her name is Tatar, since her grandmother was a true-born Tatar, her grandfather was German, she grew up in the Tatar village, not knowing a word in German. She began to learn the language of her ancestors at a mature age, chose a specialty of an interpreter, graduated from the German department of the philological faculty. Now she is one of the most prominent activists of the cultural autonomy movement, an employee of the House of
German-Russian Friendship (Kazan). A polyglot Guzel speaks the languages that she put in the following order: Deutsch, English, Tatar, Russian. So it is German,that she considers as the native language. The second example is Mariam A., a professor at the Alma-Ata University, who grew up in a Kazakh village, the German component in her life is negligible: she does not know the language, neither her name and surname reflects the German component, but the socalled "genetic memory" functions at the level of interest in German cultural heritage.

Instead of the term "bilingual", it is recommended to use the term "binational personality" to characterise the current generation of German-Russian and RussianGerman bilinguals. This term reflects not only the existence of a bi-international worldview but also a type of mutual influence-synthesis of two ethnolinguistic cultures, and a new level of perception and consciousness.

This research will serve as a future research base for the researchers to identify: $A$ ) the reasons of rejection of one of the native languages (and cultures) and the resumption of its use? B) to further probe whether the Russian Germans in the second and subsequent generations after settling in the new conditions become naturally balanced bilinguals (which language/linguocultural combinations prevail - the question of the sustainability of "new status"languages, the Tatar, Kazakh languages when changing the cultural and linguistic environment)? C) A great achievement would be the compilation of a dictionary of personal names of Russian Germans, including at least 1,000 anthroponyms; the researchers are already working on the dictionary.

Perhaps, in the modern period, serious fluctuations also occur in the anthroponymycon of Russian Germans: under the influence of personal names of the surrounding ethnic groups, changes also occur in the sound-graphic composition of anthroponyms, that is, sociocultural and historical changes, and they lead to internal changes in language units. "The studied precedential situations represent a complex system of encoded text units having a cultural 
identity and occupy a dominant position in the structure of verbal behaviour of language personality" (Kostomarov and Bolotnikova, 2015, p. 70).

In conclusion, the researchers' would like to cite an excerpt from a letter from one of the activists of the German movement in Tyumen Victor Groo:

In the annex, I send you the answers for suggested questions. But most importantly, I want to sincerely thank you for the great contribution that you make to the popularisation of my people. Thank you very much! There is an interesting fact in my life. When the parents built our house in Krasnoturinsk in 1961, we had neighbours - a Tatar family with the surname Yusupov. So, the Tatar, their son Ilfat, taught me the Russian language. Best regards, GrooV.Ya.

Overall the findings reveal how the German nameswas intertwined and mixed up in the relations of ethnic groups of Russia. This wealth must be preserved and protected, since the ethnic groups, names and links between them are often fragile, thin and can be torn. "The 21st century has brought globalisation of people's lives and education. Dramatic economic, political and natural cataclysms have made our planet's population mobile and that concerns not only highly developed countries but also the so-called third world countries" (Koudrjavtseva et al., 2015, p. 124).

The approach to resolving issues related to this topic can get a positive impetus if today's phenomenon and today's problems of Russian Germans (cultural and linguistic ones) become more understandable in a historical context, with a focus on modern and information-rich, technological world of human contacts.

\section{References}

Arutyunyan Y. V., Drobizheva L. M., \& Susokolov of A. A. (1999). Etnosotsiology. M.: Aspekt-

Press. 271.

Aumann V. A., \& Chebotarev V. G. (2008). The Russian Germans. XXI century. Under the editorship of. Moscow: IPO "Public Sciences of Russian Germans", ANO "German Culture Center", 544.

Bogoslovskaya Z.M., \& ShchegolikhinaYu.V. (2015).Features of the concept FAMILIE represented in the biographical discourse of Russian Germans. Procedia - Social and Behavioral Sciences, 200, 167-173.

Bozhkova, G. N., Shastina, E. M., Kalimullina, O. V., \& Shatunova, O. V. (2019). Study of literary images of gifted characters in optional activities as a means to develop capable and talented youth. Space and Culture, India, 7(1), 264-273. doi:10.20896/saci.v7i1.463

Chebotaryova V. G. (1997). The German colonies of the Russian Empire - "the state in the state". Ethnographic Review, 1, 127-144.

Danilova J.J., Salimova D.A., \& Ivygina A.A. (2016). "German Mark" in the History of Russian Literature: The role of Russian Germans in Social and cultural life of Russia. International Journal of Humanities and Cultural Studies (IJHCS). (August, Special Issue), 108-116.

Dinges J. (2006). The identification of the Russian Germans in the German-speaking countries of Europe. Socialinisdarbas, 5(1), 5056.

Dolgih M., \& Asatiani E. (2015, 16 April). Fiveyears period of responsibility. National focus. Annex to the ArgumentyNedeli weekly, 11.

Erikson E. H. (1968). Identity, youth and crisis. New York: W. W. Norton Company. Frolova, I., Voronkova, O., Alekhina, N., Kovaleva, I., Prodanova, N., \& Kashirskaya, L. (2019). Corruption as an obstacle to sustainable development: A regional example.

Entrepreneurship and Sustainability Issues, 7(1), 674-689. doi:10.9770/jesi.2019.7.1(48) German A. A., Ilarionova T. S., \& Pleve I. R. (2005). History of the Germans of Russia: reader: adj. to textbook. Manual, History of the Germans of Russia, Moscow: MSK-press: BIZ, 414

German surnames. Research Center of Moscow State University Lomonosov. Retrieved on 11 August 2019 from, http://www.mgufam.ru/pf015.html 
Hedderich, Norbert (2010). Review of Richard D. Lewis, When cultures collide: Managing successfully across cultures/global business languages, 4. Retrieved on 11 August 2019 from, http://docs.lib.purdue.edu/gbl/vol4/iss1/12 Koudrjavtseva E. L., Salimova D. A., \& Snigireva L. A. (2015). Russian as native, non-native, one of natives and foreign languages: Questions of terminology and measurement of levels of proficiency. Asian Social Science, 11 (14) Kostomarov P., \& Bolotnikova O. (2015). The peculiarities of precedential situations in the discourse of the representative of Volga Germans of Siberia. Procedia-Social and Behavioral Sciences, 206, 67-70.

Long, M. (1996). The role of the linguistic environment in second language acquisition. In Handbook of Second Language Acquisition, W. C. Ritchie \& T. K. Bhatia (eds.), 413- 468. San Diego, CA: Academic Press.

Magsumov, T.A. (2019). Gender re(e)volution of commercial schools in Russia in the early XX century. Woman in Russian Society, 1, 133-144. doi: 10.21064/WinRS.2019.1.12

Montrul S. (2008). Incomplete acquisition in bilingualism. Re-examining the age factor/ $\mathrm{S}$. Montrul - Amsterdam: John Benjamins, 312 p. [Series on Studies in Bilingualism]. Pavlyshyn, L., Voronkova, O., Yakutina, M., \& Tesleva, E. (2019). Ethical problems concerning dialectic interaction of culture and civilization. Journal of Social Studies Education Research, 10(3), 236-248.
Russian nemtsy. XXI century: materials of the International scientific and practical conference and sociological poll. Moscow 2008: M, 2011 of 372 pages.

Saenko, N., Voronkova, O., Volk, M., \& Voroshilova, O. (2019). The social responsibility of a scientist: Philosophical aspect of contemporary discussions. Journal of Social Studies Education Research, 10(3), 332-345. Salimova D., \& Johnson H. (2014). Difficulties in the teaching of Russian as a foreign language: The perspectives of an ethnically Tatar specialist in Russian philology and an American student. Life Science Journal; 11 (5s), 219-223.

Salimova D.A., \& Danilova J.J. (2016). Problems of ethnic-cultural codes preservation, ethnic and self-identification of the Russian Germans. International Journal of Humanities and Cultural Studies, (August, Special Issue), 100-107.

Salimova D. A., Danilova Y.Y., \& Kropotkina I.E. (2015). Historical and social approach to a problem of language and culture of the Russian Germans of the Volga region (on material of the published archival documents). Political linguistics. Yekaterinburg, 4 (54), 134- 139. Vormsbekher G. G. (2009). In interests the State Russian. The Free Idea, 8 (1605), 199-209.

\section{Acknowledgements}

The authors express great appreciation to all the respondents for the provision of information and active participation in conversations. 